\title{
Fisheries Management in the Black Sea-Pros and Cons
}

\author{
Violin S. Raykov ${ }^{1 *}$ and Ertug Duzgunes ${ }^{2}$ \\ ${ }^{1}$ Department Marine Biology and Ecology, Institute of Oceanology-Bulgarian Academy of Science, Varna, Bulgaria, ${ }^{2}$ Faculty \\ of Marine Science-Surmene, Karadeniz Technical University, Trabzon, Turkey
}

Keywords: Black Sea, fisheries management, governance, regulations, shared stocks, human activities

\section{INTRODUCTION}

\section{OPEN ACCESS}

Edited by:

Francesco Colloca,

Consiglio Nazionale Delle Ricerche

(CNR), Italy

Reviewed by:

Katrine Soma,

Wageningen University \& Research,

Netherlands

Vladislav Shliakhov,

AzNIIRKH, Russia

Nazli Demirel,

Istanbul University, Turkey

Alessandro Mannini,

Joint Research Centre (JRC), Italy

${ }^{*}$ Correspondence:

Violin S. Raykov

vraykov@io-bas.bg

Specialty section:

This article was submitted to Marine Fisheries, Aquaculture and

Living Resources,

a section of the journal

Frontiers in Marine Science

Received: 30 December 2016 Accepted: 06 July 2017

Published: 24 July 2017

Citation:

Raykov VS and Duzgunes E (2017)

Fisheries Management in the Black

Sea-Pros and Cons.

Front. Mar. Sci. 4:227.

doi: 10.3389/fmars.2017.00227
About $85 \%$ of the Mediterranean and Black Sea stocks assessed are fished at biologically unsustainable levels (FAO, 2016). The experience of EU fisheries management is unique in its scope and ambition, in that it represents the only example of reconciling the concerns of a variety of coastal countries and eco-regions with diverse, if not divergent, interests into a Common Fisheries Policy, the CFP. The last revision, after adoption and several other revisions of the CFP is referred to as the 2013 CFP throughout the document. It is notable that experiences drawn from other countries' fisheries management have been considered to shape the 2013 CFP and these will likely be accounted for in reviewing future performance (Marchal et al., 2016).

The EC and GFCM are promoting a regional approach to fisheries management in the Black Sea. GFCM (2015) has adopted measures to prevent, deter and eliminate illegal, unreported and unregulated fishing in turbot fisheries in the Black Sea as well as management measures for dogfish. Both sets of measures entered into force were reinforced with additional management measures aiming to further protect the stocks in danger (GFCM, 2016). Yet the regulated stocks in EU waters represents very low percent from the total catch in Black Sea (STECF, 2015; FAO, 2016). For example, sprat catches in EU waters were estimated for 2012-2014 between 4 and 14\% and $4.6-7 \%$ for EU share of turbot catches. This opinion aims to underline the efforts toward fishery management improvement in the Black Sea in the last years but also to highlight the existing gaps and challenges in sustainable management of marine living resources in the region.

\section{BACKGROUND}

\section{Improvements of Fisheries Management}

The CFP aims to ensure that fishing and aquaculture are environmentally, economically, and socially sustainable and that they provide a source of healthy food for EU citizens. Its goal is to foster a dynamic fishing industry and ensure a fair standard of living for fishing communities. The current policy stipulates that between 2015 and 2020 catch limits should be set that are sustainable and maintain fish stocks in the long term. The EU and GFCM is showing increasing concerns about Mediterranean and Black Sea stocks, and the Commissions have in several occasions expressed the view that the recovery of Mediterranean and Black Sea stocks should now be regarded with the highest priority (EC, 2015). Following the 2013 CFP Reform, the gradual establishment of MSY as a management target for all fish stocks (including data limited stocks) may potentially render EU TAC decision-making increasingly consistent with scientific advice. Since the inception of the 2013 CFP, the EU has strengthened its management objectives (gradual establishment of MSY to all fish stocks) and conservation measures (gradual implementation of discard limitations), raising better prospects for the future sustainability of its fisheries. Another increasingly important aim is to reduce untargeted catches and wasteful practices to the minimum or avoid them altogether, through the gradual introduction of a landing obligation. Finally, the new CFP has overhauled its 
rules and management structure, with regionalization and more extensive stakeholder consultation (COM, 2015). In recent years, enormous strides have been made in improving the knowledge and conservation of the region's living marine resources. Management plans are increasingly advocated as an essential tool for fisheries management (FAO, 1996, 2003). They are formal arrangements, between a fishery management authority and interested parties. Management plans specify the agreed objectives for the fishery, the rules and regulations to be applied and other information that may be relevant to fisheries management. Plans can be developed at the local, national and regional level, depending on the jurisdiction of the management authority and the characteristics of the fishery being managed. This opinion text describes recent efforts by the GFCM to apply plans aimed at managing fisheries in the Mediterranean and the Black Sea (FAO, 2016). Work has been under way to develop multiannual management plans for the Black Sea, particularly with regard to turbot fisheries (GFCM, 2014). It was concluded that due to the importance of anchovy, both from a socio-economic point of view and as a key element of the Black Sea ecosystem, and considering its wide distribution and migration patterns as well as the implication, at different levels, for anchovy fisheries in all riparian countries, a GFCM sub regional multiannual management plan should be implemented (GFCM, 2015).

\section{Landing Obligation}

With introduction of the landing obligation, the fishing opportunities proposed shall reflect the change from amount landed to amount caught. This is done on the basis of the received scientific advice for the fish stocks in fisheries as referred to in Article 15(1) of Regulation (EU) No 1380/2013. Landing obligation is in force for Black Sea EU countries. For the non EU countries in Black Sea, with total catch more than $80 \%$, for the time being this obligation is not applicable.

\section{Stock Assessments}

The conclusions of the third SGSABS meeting reported the status of the Black Sea turbot (Psetta maxima) population as both "overexploited" and "in overexploitation." Similarly, the Black Sea anchovy (Engraulis encrasicolus ponticus), the Black Sea horse mackerel (Trachurus mediterraneus ponticus), the red mullet (Mullus barbatus) and the whiting (Merlangius merlangus) populations were found to be "in overexploitation." Instead, the piked dogfish (Squalus acanthias) population was considered to be "depleted" at the Black Sea scale. In contrast, the Black Sea stock of sprat (Sprattus sprattus) was deemed to be sustainably exploited (Table 1). The SGSABS advised implementing a recovery plan for turbot and piked dogfish as well as the reduction of fishing mortality for all other stocks with the exception of sprat, for which the advice was not to increase fishing mortality (EC, 2016; GFCM, 2016).

\section{DISCUSSION}

Experience with fisheries management worldwide shows that in order to successfully manage the renewable resources of a marine area, compliance of all parties harvesting common resources to a common framework and their agreement on common objectives are both required. The parties should agree on compatible, effective and cost-effective regulations, on the allocation of resources, and on details of implementation of a common fisheries management regime outside territorial waters. These details should be spelled out explicitly in a management plan, which should be upgraded at intervals of 5-10 years. These activities should be reported on following an uninterrupted annual cycle of meetings between the parties concerned, including permanent working parties of national experts, panels on special issues, and commissions made up of accredited government representatives (Caddy, 1999). Some targeted species, such as shellfish, may be relatively static and for management purposes considered to be fully resident in national waters. However the major capture fisheries in the Black Sea migrate within the Black Sea, and are shared with other Black Sea stakeholders. The difficulty of managing fisheries is particularly reflected in the targets assigned to conservation objectives and how management actions are taken to meet these objectives in the short-medium term through to the long term. However, it is typical of political systems that the short-term view is prioritized over the long term (Holden, 1994). Proper management of shared stocks must involve negotiation with stakeholders throughout the range of the species. International agreements and national initiatives may force countries to prepare common fisheries management plans in near future. So, every country should be ready for such actions (Duzgunes and Erdogan, 2008). For a number of reasons which will be alluded to in this text, the Black Sea fisheries community has not been successful in implementing such cooperative activities under all of the above headings, or in "closing the circle" by putting together a working management cycle (Caddy, 1999). The GFCM focused on work toward the adoption of specific recommendations to revert the negative situation of fisheries in the region. However, the information on the status of Black Sea stocks is sparse, with few stocks being regularly assessed and with short time series for these assessments. There are still important uncertainties in the different stock assessments (e.g., estimation of total catches which also includes discards and IUU fishing activity, problems with the coverage of fisheries independent surveys, etc.). Furthermore, the Black Sea is one of the world's most isolated seas from the major oceans and it is the largest anoxic body of water on the planet. This sea is under heavy anthropogenic stress and its marine living resources need protection. Considering the particular characteristics of this sea and the specific challenges it faces in developing management advice, an ecosystem-based management approach that acknowledges the peculiarities of this sea is called for (GFCM, 2016). The level of exploitation varies in the years, as the fishing effort (Van Hoof, 2010) and fishing mortality have been changed during different periods with regards the changes in ecosystem and economic reasons, mainly. As regards the important key species in the Black Sea ecosystem, the measures for sustainable utilization must include wider ecosystem considerations. In this view, measures that advice incorporation of ecosystem approach and rules and guidelines provided by "precautionary approach" (FAO, 1996) 
TABLE 1 | Species, data type used for stock assessments, time series, methodology used, stock status, and scientific advice for 7 fish species in Black Sea (GFCM, 2016).

\begin{tabular}{|c|c|c|c|c|c|c|c|c|}
\hline GSA & Species & Data type & $\begin{array}{l}\text { Time } \\
\text { series }\end{array}$ & $\begin{array}{l}\text { Methodology } \\
\text { used }\end{array}$ & Stock status & $\mathbf{F}_{\text {curr }} / \mathbf{F}_{\text {lim }}$ & $\mathbf{B}_{\text {curr }} / \mathbf{B}_{\text {lim }}$ & Advice \\
\hline 29 & Turbot (Psetta maxima) & $\begin{array}{l}\text { Total landings; catch-at-age; } \\
\text { weight-at-age; natural mortality; } \\
\text { maturity ogive; tunning indices }\end{array}$ & 1950-2014 & SAM & $\begin{array}{l}\text { Overexploited and } \\
\text { in overexploitation }\end{array}$ & 5.38 & 0.29 & $\begin{array}{l}\text { Implement a } \\
\text { recovery plan }\end{array}$ \\
\hline 29 & $\begin{array}{l}\text { Anchovy } \\
\text { (E.encrasicolus) }\end{array}$ & $\begin{array}{l}\text { Total landings; catch-at-age; } \\
\text { weight-at-age; natural mortality; } \\
\text { maturity ogive; tunning indices } \\
\text { (Turkish CPUE) }\end{array}$ & 1988-2014 & XSA & In overexploitation & 1.33 & $\ldots$ & $\begin{array}{l}\text { Reduce fishing } \\
\text { mortality }\end{array}$ \\
\hline 29 & $\begin{array}{l}\text { Picked dogfish } \\
\text { (Squalus acanthias) }\end{array}$ & $\begin{array}{l}\text { Catch-at-age; weight-at-age; maturity } \\
\text { ogive; tunning indices (Romanian } \\
\text { CPUE) }\end{array}$ & 1989-2014 & XSA & Depleted & 3 & $\cdots$ & $\begin{array}{l}\text { Implement a } \\
\text { recovery plan }\end{array}$ \\
\hline 29 & Sprat (Sprattis sprattus) & $\begin{array}{l}\text { Catch-at-age; weight-at-age; maturity } \\
\text { ogive; tunning indices (Turkey and } \\
\text { Ukraine CPUE and pelagic surveys } \\
\text { from Romania and Bulgaria) }\end{array}$ & 1995-2014 & ICA & $\begin{array}{l}\text { Sustainably } \\
\text { exploited }\end{array}$ & 0.8 & $\ldots$ & $\begin{array}{l}\text { Do not increase } \\
\text { fishing mortality }\end{array}$ \\
\hline 29 & $\begin{array}{l}\text { Horse mackerel } \\
\text { (Tr. mediterraneus) }\end{array}$ & $\begin{array}{l}\text { Total landings; catch-at-age; } \\
\text { weight-at-age; natural mortality; } \\
\text { maturity ogive; tunning indices } \\
\text { (Turkish CPUE) }\end{array}$ & 2005-2014 & XSA & In overexploitation & 1.96 & $\ldots$ & $\begin{array}{l}\text { Reduce fishing } \\
\text { mortality }\end{array}$ \\
\hline 29 & $\begin{array}{l}\text { Red mullet (Mullus } \\
\text { barbatus) }\end{array}$ & $\begin{array}{l}\text { Catch-at-age; weight-at-age; natural } \\
\text { mortality; maturity ogive; tunning } \\
\text { indices (Turkish CPUE) }\end{array}$ & 1990-2014 & XSA & In overexploitation & 1.67 & $\ldots$ & $\begin{array}{l}\text { Reduce fishing } \\
\text { mortality }\end{array}$ \\
\hline
\end{tabular}

have to be taken into account in proper management of the key fish populations (Raykov and Zlateva, 2015).

The term "management" usually is interpreted as series of regulatory measures introduced in the fishery practice with no doubt, positive influence on the general condition of marine living resources. On the other hand, similar restrictions could not lead conceptually to the "management policy" if they are not systemized with clearly formulated aims and prerogatives. In the presence of introduced "closed area," "closed season," "minimum mesh size," and other regulations, altogether all of these measures could not serve as restrictions over the yield capacity, i.e., could not influence the fishing effort. The main priority in such a conception is a precautionary approach and responsible fishery practice in force. It could "work" properly with quota principle implementation, together with more effective system control. It is hard for any single country to follow these regulations and it is harder for all Black Sea countries to do so, because they are exploiting resources from shared fish stocks. In order to have an effective management on these stocks, joint stock assessments and co-operated fisheries management plans are needed. On this basis, the allocation of the catches for the separate Black Sea country could be established. Hence, it could be assumed that management of the marine living resources shall be fulfilled in its incomplete form, under the national jurisdiction prescript, as they are. The future of fisheries management in Black Sea is intrinsically linked with the setting of cross-sectoral "Maritime Policy" and "Marine Strategy Framework Directive" (EC, 2008) which deal with the cumulative impact of human activities. Implementation of management procedure involves the practical interpretation of objectives and procedures, and implementation of instructions for compliance, fishery monitoring and enforcement. The public and industry are more inclined to support measures upon which they have been consulted, so public participation at the implementation phase is critical. Public advertising of issues may help in this regard. Peer review of assessments and transparency in the process prevent errors (Pilling et al., 2008). In the Black Sea region the ecosystem approach has not been systematically applied in management, neither it has been previously recognized as a needful and inevitable framework to sustain healthy environment. The scientific message of complexity of ecosystems should reach the decision makers in a way raising their awareness on the necessity to manage the ecosystems in their integrity of health, services and goods. There is an increasing need for adoption of the ecosystem approach to exploitation of marine natural resources to promote ecological, environmental, economic, and social sustainability and preserve biodiversity in the Black Sea region.

\section{CONCLUDING REMARKS}

The lack of common fisheries management and management plans, overexploitation and unknown use of the resources, lack of bio-economic analyses, significant loss of revenue and unsustainable development are among most serious problems facing Black Sea fisheries.

As regards Black Sea, it is more properly to put the accent on the separate regulations of the fishery, instead of its integral management. These regulations concern in very small extension the shared fish stocks, which are exploited without sufficient control. The future of fisheries management in Black Sea is intrinsically linked with the setting of cross-sectoral Maritime Policy and Marine Strategy Framework Directive which deal with the cumulative impact of human activities. Major efforts for multilateral cooperation among the riparian countries will be 
needed in order to improve the governance of the shared and migratory stocks in long term.

\section{AUTHOR CONTRIBUTIONS}

VR and ED: Substantial contributions to the conception or design of the work; or the acquisition, analysis, or interpretation of data for the work; Drafting the work or revising it critically for important intellectual content; Final approval of the version to be published; Agreement to be accountable for all aspects of

\section{REFERENCES}

Caddy, J. F. (1999). Recent Experience and Future Options for Fisheries Assessment and Management in the Black Sea: A GFCM Perspective. Available online at: https://myfisherywork.files.wordpress.com/.../fisheries-in-the-b

COM (2015). 239 COMMISSION DELEGATED REGULATION (EU) 2015/1778 of 25 June 2015 Establishing Fisheries Conservation Measures to Protect Reef Zones in Waters Under the Sovereignty of Denmark in the Baltic Sea and Kattegat.

Duzgunes, E., and Erdogan, N. (2008). Fisheries management in the Black Sea countries. Turk. J. Fish. Aquat. Sci. 8, 181-192. Available online at: http://www. trjfas.org/abstract.php?lang=en\&id $=608$

EC (2008). Directive 2008/56/EC of the European Parliament and of the Council of 17 June 2008 Establishing a Framework for Community Action in the Field of Marine Environmental Policy (Marine Strategy Framework Directive).

EC (2015). Consultation on the Fishing Opportunities for 2016 under the Common Fisheries Policy.

EC (2016). Proposal for Council Regulation Fixing for 2017 the Fishing Opportunities for Certain Fish Stocks and Groups of Fish Stocks in the Black Sea. Brussels, 7.12.2016, COM (2016) 781 Final 2016/0386 (NLE).

FAO (1996). Precautionary Approach to Fisheries. Part 2: Scientific Papers. Prepared for the Technical Consultation on the Precautionary Approach to Capture Fisheries (Including Species Introductions) Lysekil, Sweden 6-13 June 1995. FAO Fisheries Technical paer.No.350, Part 2. Rome, 210.

FAO (2003). The Ecosystem Approach to Fisheries. FAO Technical guidance for responsible fisheries, Rome, 112.

FAO (2016). The State of Mediterranean and Black Sea Fisheries. General Fisheries Commission for the Mediterranean. Rome.

GFCM (2014). Ad-hoc Meeting of the Working Group on the Black Sea on Turbot Fisheries. Constanta.

GFCM (2015). Report on the management of anchovy fisheries in the Black Sea (WKMEASURES - BS). Trabzon.

GFCM (2016). Sub-regional Group on Stock Assessment (SGSABS) for the Black Sea Burgas. Bulgaria. the work in ensuring that questions related to the accuracy or integrity of any part of the work are appropriately investigated and resolved.

\section{ACKNOWLEDGMENTS}

The authors thank Dr. Ali Cemal Gücu for kind invitation to contribute with this opinion. The blind reviewers and editors of the manuscript are highly acknowledged.

Holden, M. (1994). The Common Fisheries Policy: Origin, Evaluation and Future. Oxford: Fishing News Books.

Marchal, P., Andersen, J. L., Aranda, M., Fitzpatrick, M., Goti, L., Guyader, O., et al. (2016). A comparative review of fisheries management experiences in the European Union and in Other Countries worldwide: Iceland, Australia, and New Zealand. Fish Fish. 17, 803-824. doi: 10.1111/faf.12147

Pilling, G., Apostolaki, P., Failler, P. Floros, C., Large, P. A., Morales-nin, B. et al., (2008). "Assessment and management of datapoor fisheries," in Advances in Fisheries science: 50 years on from Beverton and Holt, eds A. Payne, J. Cotter, and T. Potter (Lowestoft: Blackwell Publishing; CEFAS), 280-305.

Raykov, V. S., and Zlateva, I. (2015). "Fish stock indicators as measure for sustainability: black sea sprat case," in Progressive Engineering Practices in Marine Resource Management, eds. I. Zlateva, V. Raykov, and N. Nikolov (Hershey, PA: IGI Global), 65. doi: 10.4018/978-1-4666-8333-4.ch004

STECF (2015). Scientific, Technical and Economic Committee for Fisheries (STECF) - Black Sea assessments (STECF-15-16). Luxembourg: Publications Office of the European Union, 284.

Van Hoof, L. (2010). Tools for Fishing Fleet Management. European Parliament study, Directorate General for Internal Policies, Policy Department B: Structural and Cohesion Policies Fisheries, 61.

Conflict of Interest Statement: The authors declare that the research was conducted in the absence of any commercial or financial relationships that could be construed as a potential conflict of interest.

Copyright (c) 2017 Raykov and Duzgunes. This is an open-access article distributed under the terms of the Creative Commons Attribution License (CC BY). The use, distribution or reproduction in other forums is permitted, provided the original author(s) or licensor are credited and that the original publication in this journal is cited, in accordance with accepted academic practice. No use, distribution or reproduction is permitted which does not comply with these terms. 